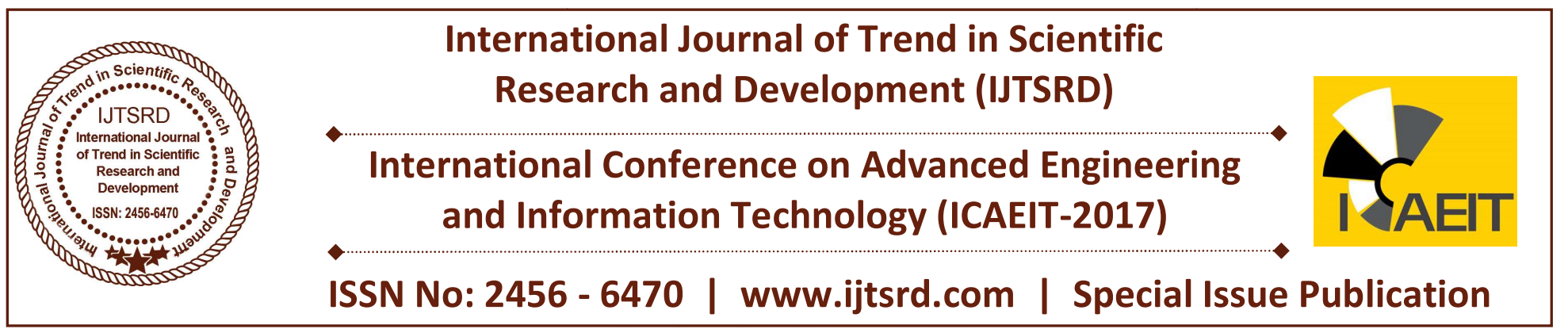

\title{
Analysis of Retrofiton School Building With Shear Wall and Steel Bracing
}

\author{
Fauzan $^{1}$, Febrina. I. ${ }^{1}$, Farizzia. S. ${ }^{2}$, Yogii. R. ${ }^{3}$, Zev A. J. ${ }^{4}$ \\ ${ }^{1}$ Lecturerat Department of CivilEngineering, Andalas University, Padang City, Indonesia \\ ${ }^{2}$ Construction Engineerat PT Total Bangun Persada, Indonesia \\ ${ }^{3}$ Enginner Staff at PT Waskita Karya, Indonesia \\ ${ }^{4}$ Studentat Department of Civil Engineering, Andalas University, Padang City, Indonesia
}

\section{ABSTRACT}

The earthquake on 30 September 2009with7,6 magnitude occurred in West Sumatera and it caused the damage to both physical public facilities and infrastructures. The education sectors suffered from structural damage to the school buildings. In order to establish of the new Indonesian Seismic Code, SNI031726-2012, it will affect to the performance of structures which was built before the establishment of the new seismic code, in which the building may not be adequate to with stand the working loads. In this study, the performance and structural strength of a two-story RC school building (SMAN3 Batusangkar) designed using previous seismic code (SNI03-17262002) and it was constructed before2009, was evaluated based on the new seismic code. The result of evaluation on the SMAN3 Batusangkar building shows that the building cannot resist the working loads applied to the structure, especially the earthquake loads, so the building structure needs to be retrofitted. Two retro fitted methods of the builiding were proposed in this study, they are using shear wall and steel bracing systems, which installed on the building frame with different locations. The addition of shear wall and steel bracing are very effective in strengthening the building structure, where the loadbearing capacity of the structure increased significantly and the building is able to resist all working loads.

Keywords: Earthquake, Retrofit, Shear Wall, Steel Bracing, School Building

\section{INTRODUCTION}

In recent years, some parts of Indonesia experienced large earthquakes. It started from Aceh on December 26, 20 04, Niasand Mentawai on March and April 2005, Bengkulu on September 12and13, 2007, and the last earthquake in Pariaman on September 30, 2009. After the earthquake on September 30, 2009, the education sector suffered from structural damage of the school buildings. The 2132 classrooms were heavily damaged, 1335 were moderately damaged, and 1144 were minor damaged [1]. Schools area is strategic target as the dissemination of disaster information enter. Therefore, as a disaster risk reduction efforts of schools in Indonesia, the government of Indonesia throughs the National Agency for Disaster Management (BNPB), Ministry of Public Works, and Ministry of Education and Culture make a program called SAFE school.

Based on a history of the earthquakes that occurred in recent years, it is known that the earthquake has peak ground accelaration (PGA) greater than the PGA that has been set in the earthquake map in SNI03-1726-2002 Code [2]. So, this code is not applicable with current condition. The government through BSNI (Indonesian National Standardization Agency) has established a new seismic code, SNI03-1726-2012, Earthquake Resilience Planning Standards for Structural Building and Non-Building [3].Therefore, an evaluation or assessment of the existing building designed using the old seismic code, including school building, should be done based on the new seismic code. 


\section{Evaluation of the existing building}

In this study, the performance and structural strength of a school public building in West Sumatera, Senior High School (SMAN) 3 Batusangkar Building, was evaluated. The school was two-story RC building, which is designed using previous seismic code (SNI 03-1726-2002) and constructed before2009, so it is necessary to evaluate based on the new seismic code. The details of building are described in the Figure1 and Table1.

Table1:DetailsoftheSMAN3 Batusangkar building

\begin{tabular}{|c|c|}
\hline Structural Elements & Properties \\
\hline \multirow{4}{*}{ Beam size } & $\mathrm{B} 1(30 \mathrm{~cm} \times 65 \mathrm{~cm})$ \\
\cline { 2 - 2 } & $\mathrm{B} 2(25 \mathrm{~cm} \times 40 \mathrm{~cm})$ \\
\cline { 2 - 2 } & $\mathrm{B} 3(25 \mathrm{~cm} \times 30 \mathrm{~cm})$ \\
\cline { 2 - 2 } & $\mathrm{B} 4(30 \mathrm{~cm} \times 40 \mathrm{~cm})$ \\
\hline \multirow{2}{*}{ Column size } & $\mathrm{K} 1(30 \mathrm{~cm} \times 40 \mathrm{~cm})$ \\
\cline { 2 - 2 } Slab thickness & $\mathrm{K} 2(30 \mathrm{~cm} \times 30 \mathrm{~cm})$ \\
\hline Total height of frame & $12 \mathrm{~cm}$ \\
\hline Number of column & $5.2 \mathrm{~m}$ \\
\hline $\begin{array}{c}\text { Compressive strength } \\
\text { of concrete }\end{array}$ & $\begin{array}{c}\mathrm{K}-225 \\
\left(\mathrm{f}_{\mathrm{c}}{ }^{\prime}=18.675 \mathrm{MPa}\right)\end{array}$ \\
\hline $\begin{array}{c}\text { Yield strength of } \\
\text { reinforcement }\left(\mathrm{f}_{\mathrm{y}}\right)\end{array}$ & $320 \mathrm{MPa}$ \\
\hline Plan area & $52.5 \mathrm{mx} 10 \mathrm{~m}$ \\
\hline
\end{tabular}
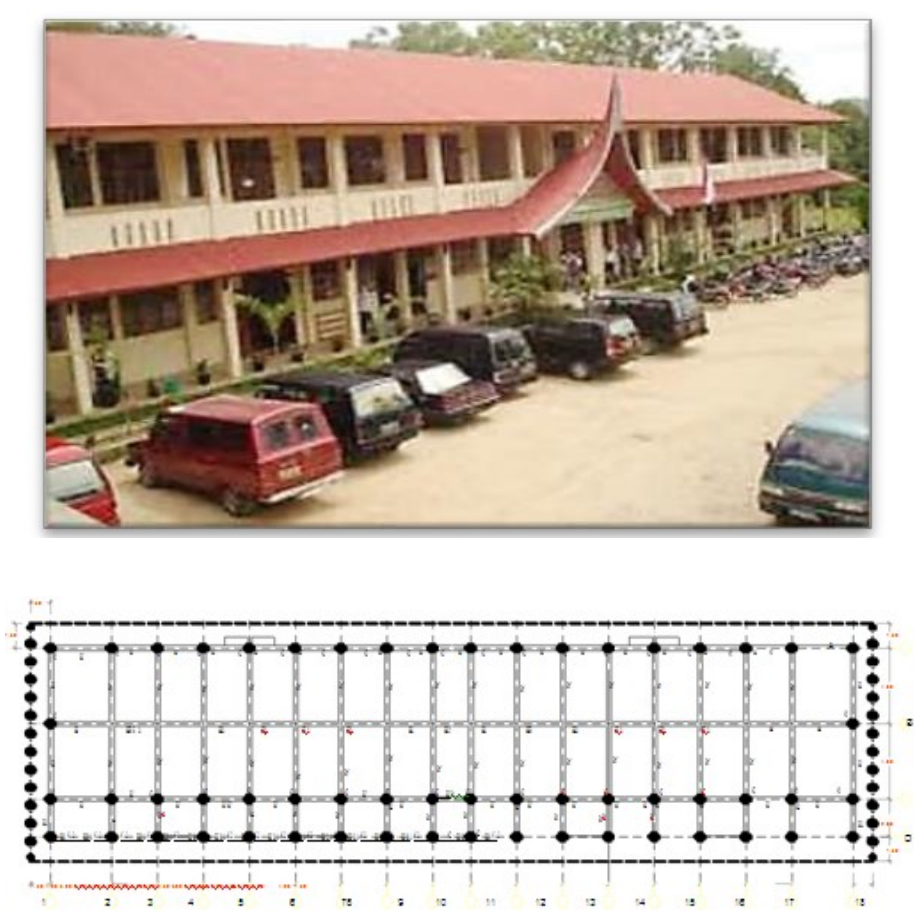

Figure1. Perspective and plan of the school building

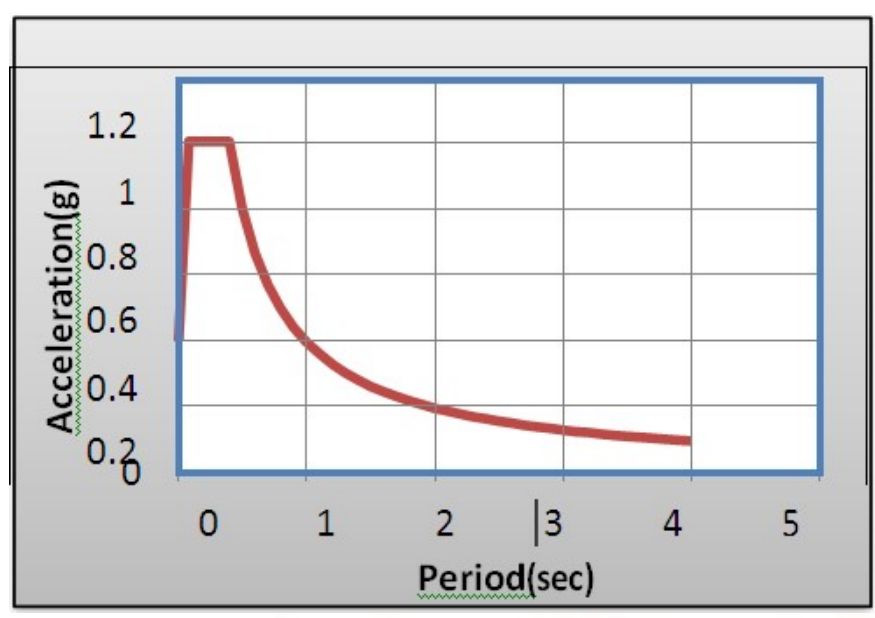

Figure2. Response spectrum graph for Batusangkar CitybasedonSNI1732-2012

Calculation and structural analysis are applied by a three-dimensional structure made of a computer program, ETABS 9.7.1[4]. The loads a retaken into account included the dead load/weigh to fits own building, live, and seismic load. An analysis of the seismic load used dynamic analysis based on SNI031726-2012Code. The minimum load for design of buildings and other structures code, SNI 1727-2013 Code, was used to calculate the working loads [5].The dynamic analysis used seismic response spectrum design for Batusangkar City, as seen in the Figure2 (source: http://puskim.pu.go.id, application design spectraofIndonesia2011)[6].

\subsection{The flexural capacity of existing columns}

Figure3 shows the P-Minter action diagram for columns of the building structure. It can be seen in the figure, there are several points of axial forces and bending moments exceed the inter action diagram, this means that the capacity of column is not strong enough to resist the working loads

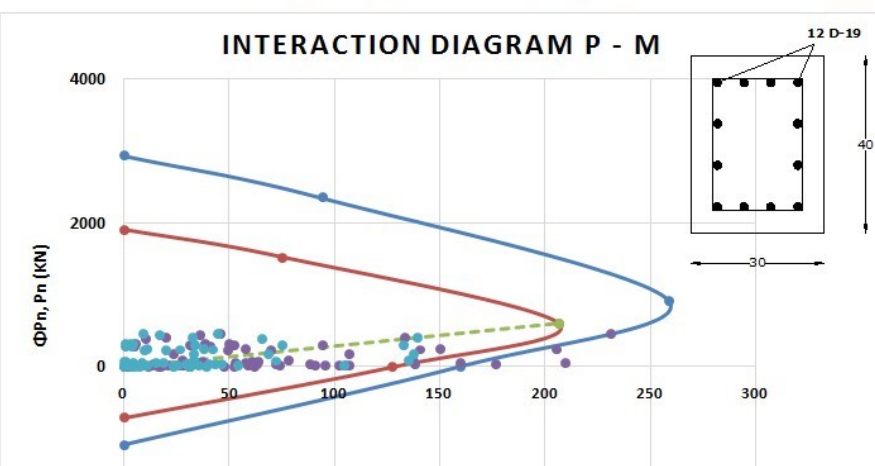

$-2000$

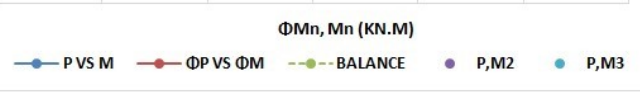




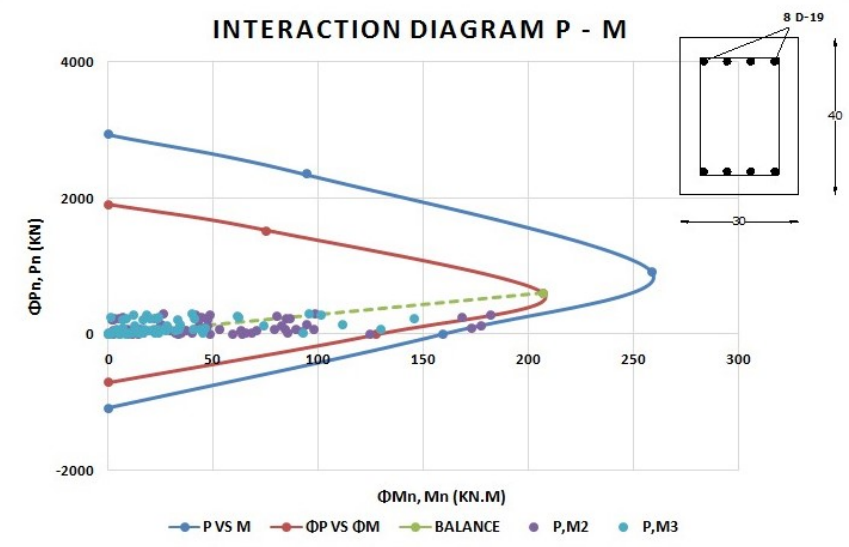

Figure3. Interaction diagram of the existing column

\subsection{The shear capacity of existing columns}

Table 2: Column shear capacity of the existing structure

\begin{tabular}{|l|l|l|l|}
\hline \multicolumn{1}{|c|}{ Column } & $\begin{array}{c}\text { Vu,ETA } \\
\text { BS }(\mathbf{k n})\end{array}$ & $\begin{array}{c}\boldsymbol{\varphi} \mathbf{V} \mathbf{n} \\
(\mathbf{k n})\end{array}$ & $\begin{array}{l}\text { Exp.(Vu } \\
\leq \boldsymbol{\varphi} \mathbf{V n})\end{array}$ \\
\hline K130/40(1 $1^{\text {st }}$ Floor $)$ & 67,15 & 103,99 & OK \\
\hline K230/30( $1^{\text {st }}$ Floor $)$ & 71,25 & 55,71 & NOTOK \\
\hline K230/30(2 $2^{\text {nd }}$ Floor $)$ & 60,4 & 55,71 & NOTOK \\
\hline
\end{tabular}

Table 2 shows the shear capacity of the columns. All columns have a ten $\mathrm{mm}$ diameter with a $200 \mathrm{~mm}$ space between two shear reinforce met. As seen in the table, the shear capacity of column $\mathrm{K} 1$ is sufficient, nominal shear is higher than the ultimate shear $(\mathrm{Vu})$. However, the shear capacity of both columns K2 (1st and 2nd floors) could not meet the requirement.

\subsection{Inter Story Drift (SNI03-1726-2012Code)}

Table3: Inter story drift of the existing structure

\begin{tabular}{|c|c|c|c|c|c|}
\hline $\begin{array}{c}\text { Sto } \\
\text { ry }\end{array}$ & $\begin{array}{c}\text { Disp. } \\
(\mathbf{m m})\end{array}$ & $\begin{array}{c}\text { DriftX } \\
(\mathrm{mm})\end{array}$ & $\begin{array}{c}\Delta \mathrm{s} \\
(\mathrm{mm})\end{array}$ & $\begin{array}{c}\Delta \mathrm{a} \\
(\mathrm{mm})\end{array}$ & $\begin{array}{c}\Delta \mathrm{s} \leq \\
\mathbf{\Delta a}\end{array}$ \\
\hline $\mathbf{2}$ & 3.6 & 5.43 & 19.910 & 51.346 & $\mathrm{OK}$ \\
\hline $\mathbf{1}$ & 3.6 & 7.75 & 28.417 & 51.923 & $\mathrm{OK}$ \\
\hline
\end{tabular}

\begin{tabular}{|l|l|l|l|l|l|}
\hline Story & $\begin{array}{l}\text { Disp. } \\
(\mathbf{m m})\end{array}$ & $\begin{array}{l}\text { Drifty } \\
(\mathbf{m m})\end{array}$ & $\begin{array}{l}\Delta \mathrm{s} \\
(\mathbf{m m})\end{array}$ & $\begin{array}{l}\Delta \mathbf{a} \\
(\mathbf{m m})\end{array}$ & $\begin{array}{l}\Delta \mathrm{s} \leq \\
\mathbf{a}\end{array}$ \\
\hline $\mathbf{1}$ & 10.93 & 10.93 & 40.08 & 51.346 & OK \\
\hline $\mathbf{2}$ & 24.1 & 13.17 & 48.29 & 51.923 & OK \\
\hline
\end{tabular}

Table 3 shows the value of inter story drift in $\mathrm{x}$ and $y$ - directions. From the table, it can be seen that maximum of the story drift for $\mathrm{x}$ and $\mathrm{y}$-direction are $0.3032 \mathrm{~m}$ and $0.04167 \mathrm{~m}$, respectively. These values are less than the allowable inter story drift of $0.04154 \mathrm{~m}$.
Based on the above analysis result of the existing building by using the new Indonesian seismic code, it can be said that the SMAN 3 Batusangkar building structure is not capable to resist the working loads.

\section{Recommendation of the retrofitting 3.1. Retrofitting of structures}

Retrofitting is a method to increase the resistant capacity of structure. A seismic retrofit provides existing structures with more resistance to seismic activity due to earthquakes. Retrofitting techniques can be classified as local and global retrofitting. Local retrofitting is the maintenance of local deficiencies in building like crushing of columns, flexure and shear failure of beams, columns and shear walls, also rebuilding infill masonry. Global retrofitting is maintenance of global deficiencies in building like plan and vertical irregularities. The global retrofit includes the addition of shear wall and steel bracing [7].

In this study, there are two retrofitted systems, shear wall and steel bracing systems which was analysed. The systems were attached on the building frames with different locations.

\subsubsection{Retrofitted with shear wall}

Shear wall system is one of the most commonly used lateral- load resisting systems in multi-story buildings. Shear wall has very high in-plane stiffness and strength which can be used to simultaneously resist large horizontal loads and support gravity loads [8]. The proposed thickness of shear wall is $25 \mathrm{~cm}$ with compressive strength of concrete (fc') is $25 \mathrm{Mpa}$. The yield strengh of the $\mathrm{D}-16 \mathrm{~mm}$ logitudinal reinforcement is $390 \mathrm{MPa}$. The yield strengh of the D-10 mm transversal reinforcement is $240 \mathrm{MPa}$. Specification detail of the shear wall in the retrofitted structure can be seen in the Figure 4.

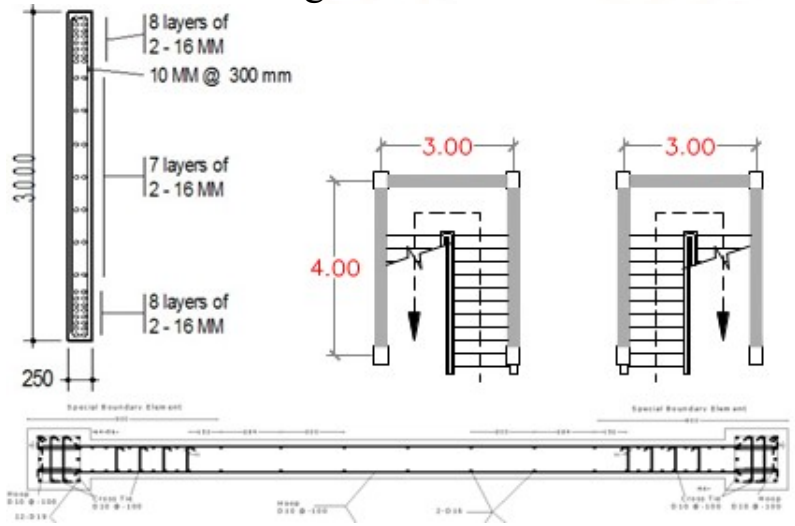

Figure4. Specification detail of shear wall 
Four different locations that added to the shear wall system on the building were modelled, as shown in Figure 6:

$>$ Model A, shear wall attached on a core area of stairs in the1st floor (Figure 6a)

$>$ Model $\mathrm{B}$, shear wall attached on a core area of stairs in the1st and 2nd floors (Figure $6 \mathrm{~b}$ )

$>$ Model C, shear wall attached on a corner area of the building in the1st floor (Figure 6c)

$>$ Model D, shear wall attached on a corner area of the building in the1st and 2nd floors (Figure 6d)

\subsubsection{Retrofitted with steel bracing}

Bracing system is one of structural system which forms an integral part of the frame. Bracing is efficient because the diagonals work in axial stress and therefore it is called for minimum member sizes in providing the stiffness and strength against horizontal shear [9]. In this study, steel bracing with the $\mathrm{V}$-inverted was selected to retrofit the existing structure. Based on the results of bracing designed calculations (with input parameters: yield strength of $390 \mathrm{MPa}$, ultimate strength of $520 \mathrm{MPa}$ and elastic modulus of $200.000 \mathrm{MPa}$ ), IWF profile with dimension of 250.250.9.14 provides enough lateral stiffness and stability. The specification detail of the steel bracing can be seen in Figure 5 .

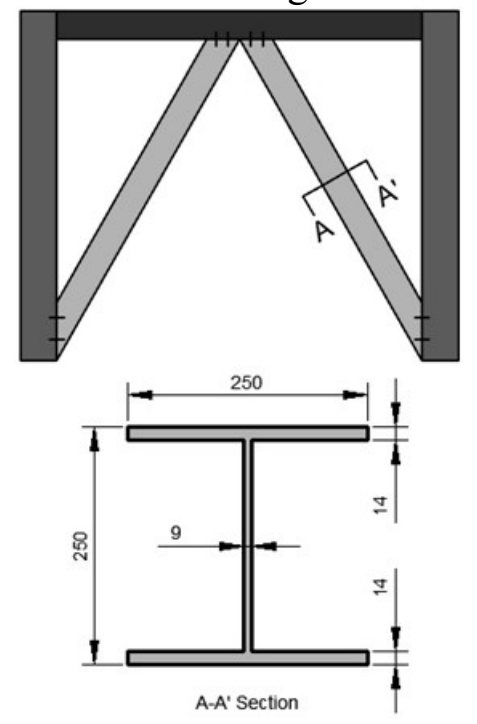

Figure5. Specification detail of steel bracing

Four different locations that added to the steel bracing system on the building were modelled, as shown in Figure 6:

$>$ Model E, the bracing attached on $\mathrm{X}$ direction both front and rear on 1st floor (Figure 6e)

> Model $\mathrm{F}$, the bracing attached in corners area $\mathrm{X}$ and $\mathrm{Y}$ directions (L shape) on 1st floor and 2nd floors (Figure 6f)
Model $\mathrm{G}$, the bracing attached in $\mathrm{X}$ and $\mathrm{Y}$ directions (U shape) on 1st and 2nd floors (Figure $6 \mathrm{~g})$

Model $\mathrm{H}$, the bracing attached in $\mathrm{Y}$ direction and central part of the building in $\mathrm{X}$ direction on 1stand 2nd floors (Figure 6h)

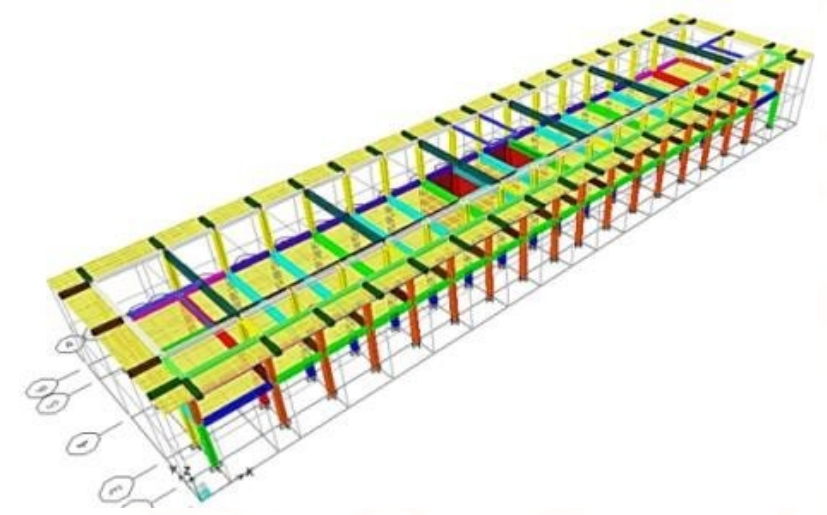

(a)ModelA

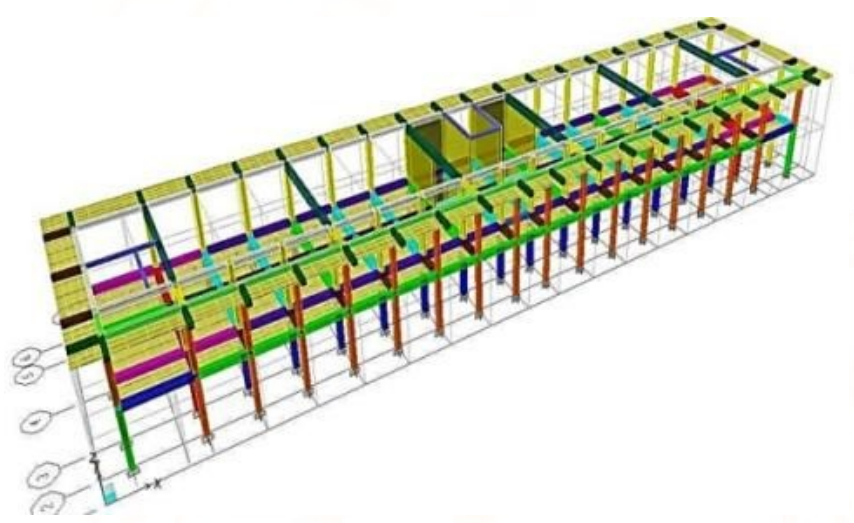

(b)ModelB

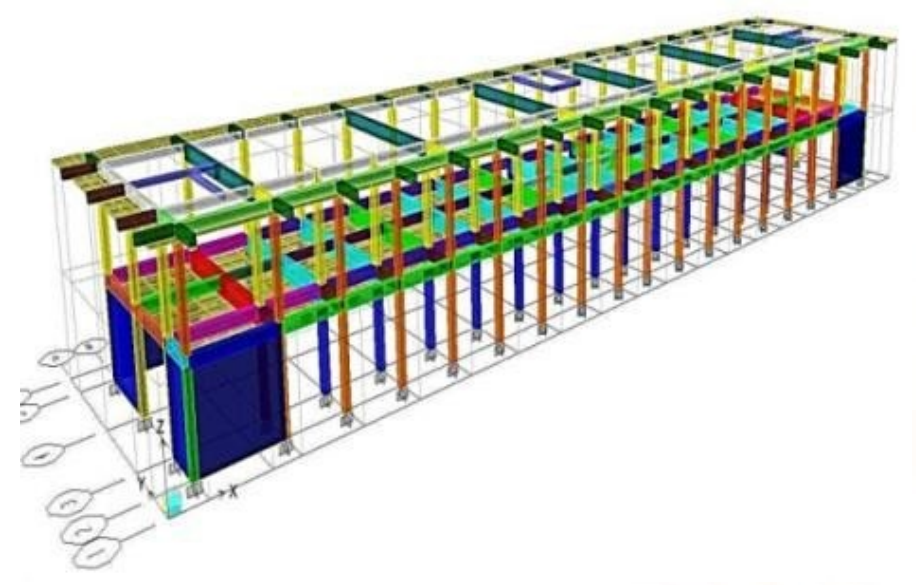

(c)Model C 


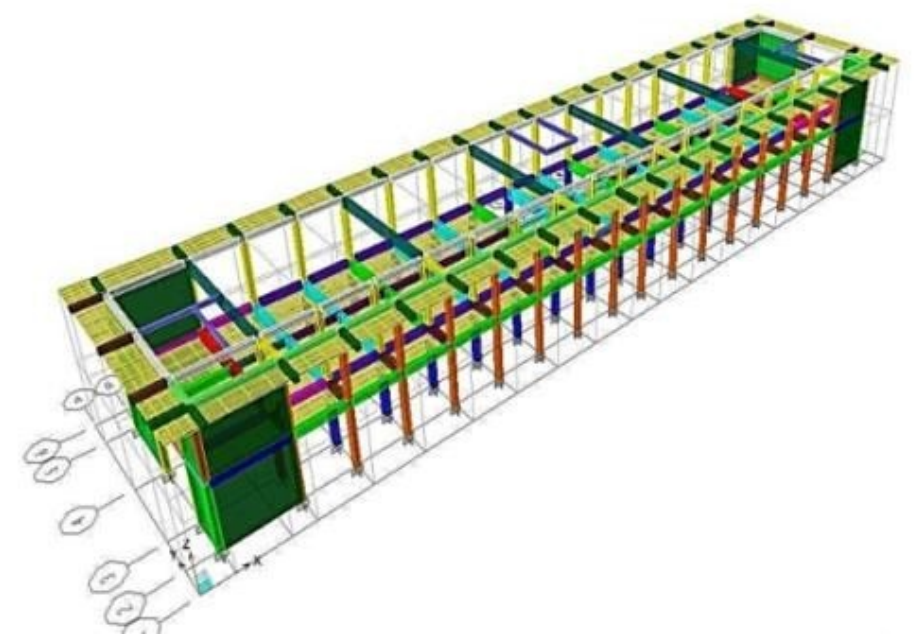

(d)Model D

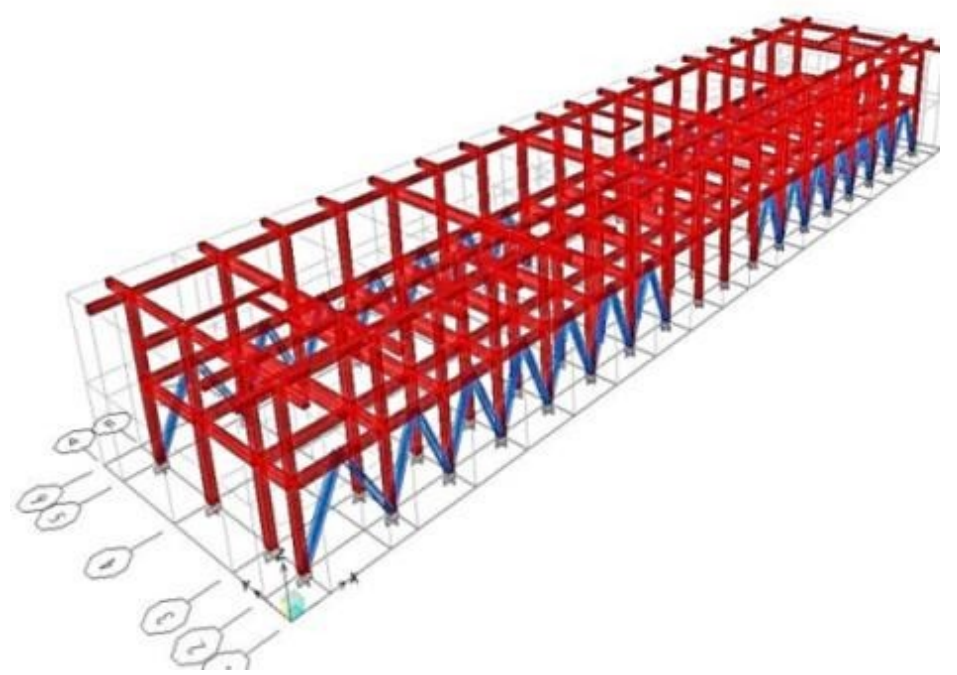

(e) Model E

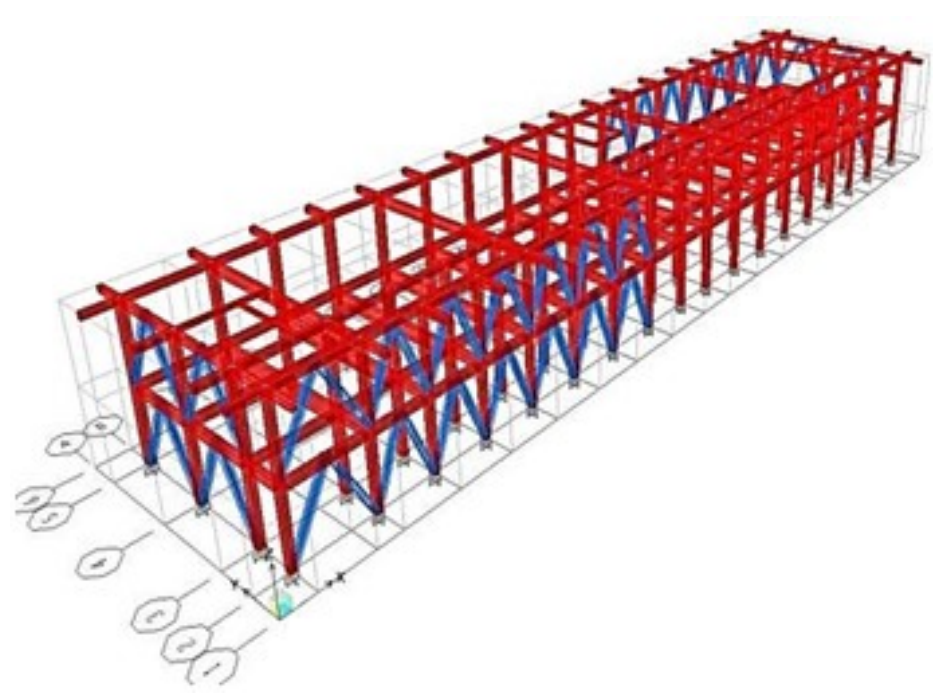

(f) Model F

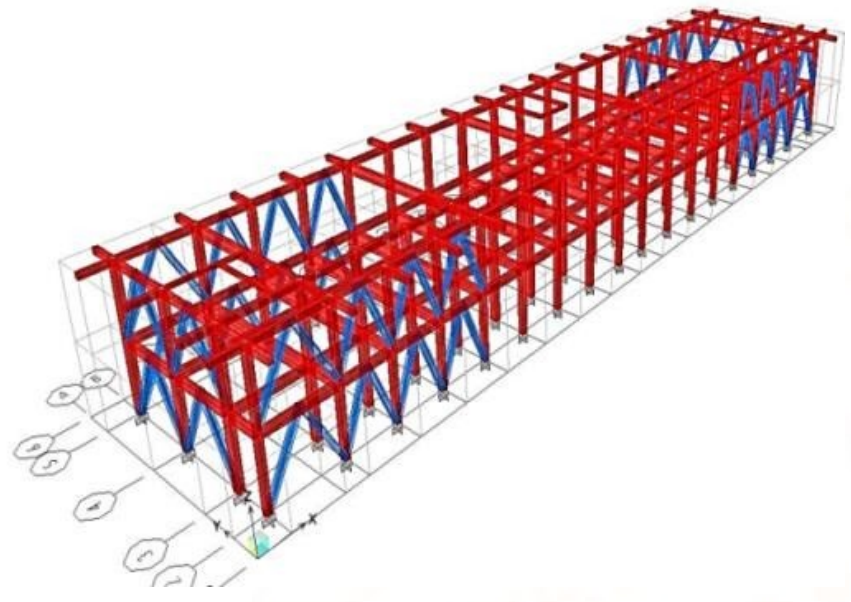

(g) Model G

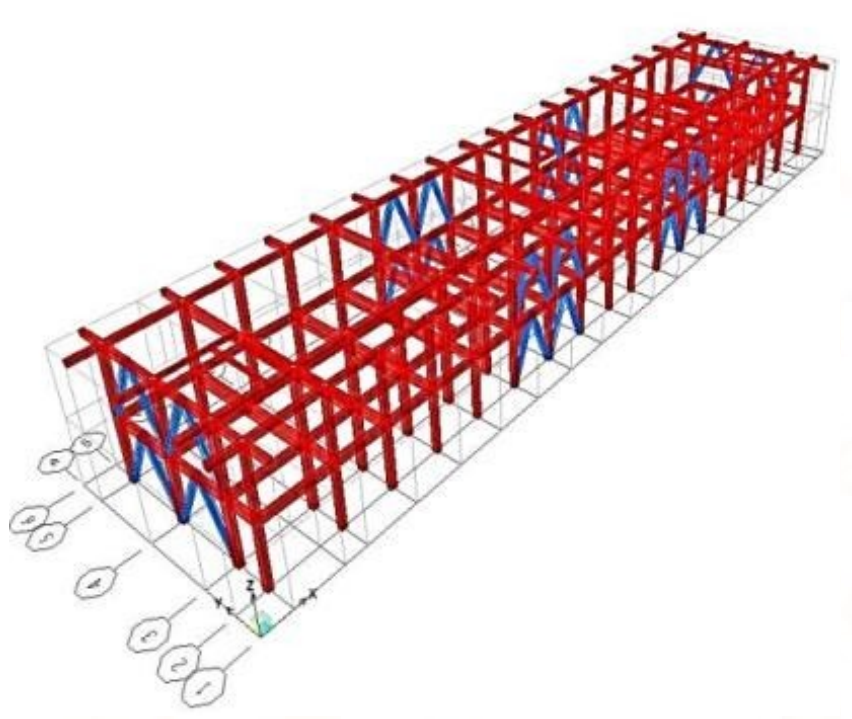

(h) Model H

Figure6. The 3-D modeling of retrofitted structures

\subsection{Analysis of retrofitted structures}

Structural analysis using ETABS v9.7.1 was carried out for all models. From the eight retrofitted building models analyzed, the result of inter story drift shows that the four models (Models A,C,E, and $\mathrm{H})$ do not meet requirement based on new seismic code, SNI 1726-2012, where the story drift exceeds the allowable drift, as shown in Table 4. Therefore, there are four models recommended for retrofitting structures: models B and D using shear wall system and models $\mathrm{F}$ and $\mathrm{G}$ using steel bracing system. The comparison for recommanded models of the retrofitted building are discussed below. 
International Journal of Trend in Scientific Research and Development (IJTSRD) | ISSN: 2456-647

Table4: Inter story drift of all retro fitted models

\begin{tabular}{|c|c|c|c|c|c|c|c|c|c|c|c|}
\hline $\begin{array}{l}\text { Mo } \\
\text { del }\end{array}$ & $\begin{array}{l}\text { Sto } \\
\text { ry }\end{array}$ & $\begin{array}{l}\text { Disp. } \\
\text { X(mm) }\end{array}$ & $\begin{array}{c}\text { Drift } X \\
(\mathrm{~mm})\end{array}$ & $\begin{array}{c}\Delta \mathrm{s} \\
(\mathrm{mm})\end{array}$ & $\begin{array}{c}\Delta \mathrm{a} \\
(\mathrm{mm})\end{array}$ & $\begin{array}{l}\Delta \mathrm{s} \leq \\
\Delta \mathrm{a}\end{array}$ & $\begin{array}{l}\text { Disp.Y } \\
\text { (mm) }\end{array}$ & $\begin{array}{l}\text { Drift. Y } \\
(\mathrm{mm})\end{array}$ & $\begin{array}{c}\Delta \mathrm{s} \\
(\mathrm{mm})\end{array}$ & $\begin{array}{c}\Delta a \\
(m m)\end{array}$ & $\begin{array}{l}\Delta s \leq \\
\Delta a\end{array}$ \\
\hline \multirow[t]{2}{*}{$\mathrm{A}$} & 2 & 0.0279 & 0.0255 & 0.0850 & 0.054 & NOT & 0.0217 & 0.014 & 0.0450 & 0.054 & $\mathrm{OK}$ \\
\hline & 1 & 0.0024 & 0.0024 & 0.0080 & 0.054 & $\mathrm{OK}$ & 0.0079 & 0.0079 & 0.0263 & 0.054 & $\mathrm{OK}$ \\
\hline \multirow[t]{2}{*}{ B } & 2 & 0.0081 & 0.0059 & 0.0197 & 0.054 & OK & 0.0182 & 0.012 & 0.0387 & 0.054 & $\mathrm{OK}$ \\
\hline & 1 & 0.0022 & 0.0022 & 0.0073 & 0.054 & $\mathrm{OK}$ & 0.0066 & 0.0066 & 0.022 & 0.054 & $\mathrm{OK}$ \\
\hline \multirow[t]{2}{*}{$\mathrm{C}$} & 2 & 0.0234 & 0.0225 & 0.0750 & 0.054 & NOT & 0.0164 & 0.012 & 0.0397 & 0.054 & $\mathrm{OK}$ \\
\hline & 1 & 0.0009 & 0.0009 & 0.0030 & 0.054 & $\mathrm{OK}$ & 0.0045 & 0.0009 & 0.015 & 0.054 & $\mathrm{OK}$ \\
\hline \multirow[t]{2}{*}{$\mathrm{D}$} & 2 & 0.0149 & 0.0141 & 0.047 & 0.054 & $\mathrm{OK}$ & 0.0169 & 0.012 & 0.041 & 0.054 & $\mathrm{OK}$ \\
\hline & 1 & 0.0008 & 0.0008 & 0.0027 & 0.054 & $\mathrm{OK}$ & 0.0046 & 0.0046 & 0.0153 & 0.054 & $\mathrm{OK}$ \\
\hline \multirow[t]{2}{*}{$\mathrm{E}$} & 2 & 0.0232 & 0.023 & 0.0767 & 0.054 & NOT & 0.021 & 0.012 & 0.04 & 0.054 & $\mathrm{OK}$ \\
\hline & 1 & 0.0002 & 0.0002 & 0.0007 & 0.054 & $\mathrm{OK}$ & 0.0089 & 0.0089 & 0.0297 & 0.054 & $\mathrm{OK}$ \\
\hline \multirow[t]{2}{*}{$\mathrm{F}$} & 2 & 0.016 & 0.016 & 0.0533 & 0.054 & $\mathrm{OK}$ & 0.012 & 0.0095 & 0.0317 & 0.054 & $\mathrm{OK}$ \\
\hline & 1 & 0.0001 & 0.0001 & 0.0000 & 0.054 & $\mathrm{OK}$ & 0.0021 & 0.0021 & 0.007 & 0.054 & $\mathrm{OK}$ \\
\hline \multirow[t]{2}{*}{$\bar{G}$} & 2 & 0.0162 & 0.0162 & 0.054 & 0.054 & $\mathrm{OK}$ & 0.012 & 0.0098 & 0.0327 & 0.054 & $\mathrm{OK}$ \\
\hline & 1 & 0.0001 & 0.0001 & 0.0000 & 0.054 & NOT & 0.0021 & 0.0021 & 0.007 & 0.054 & $\mathrm{OK}$ \\
\hline \multirow[t]{2}{*}{$\overline{\mathrm{H}}$} & 2 & 0.026 & 0.0238 & 0.0793 & 0.054 & OK & 0.021 & 0.0138 & 0.046 & 0.054 & $\mathrm{OK}$ \\
\hline & 1 & 0.0022 & 0.0022 & 0.0073 & 0.054 & OK & 0.0076 & 0.0076 & 0.0253 & 0.054 & $\mathrm{OK}$ \\
\hline
\end{tabular}

\subsection{The location point of columns and beams to compared the structural responses}

The location point of columns and beams to compare structural response can be seen in Figure 7. The positions are taken from one interior beam and another one interior column of the center of each floor.

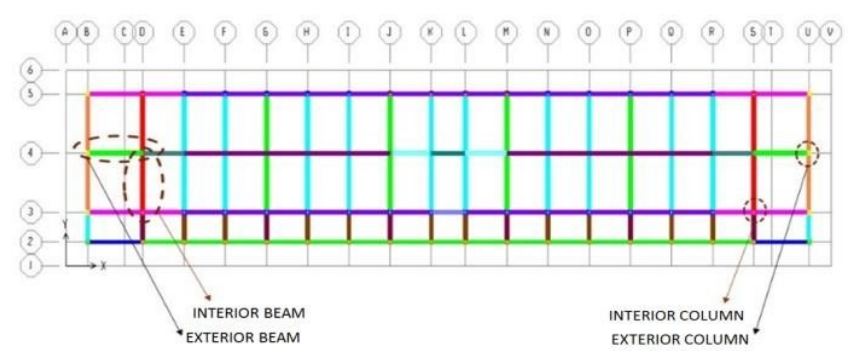

Figure 7. Location point of columns and beams to compare the structural response

\section{Results and discussion}

\subsection{The Internal Force in Beams}

The comparison of shear force on the beam between Existing and retrofitted building is shown in Table5. From the table, it can be seen that the building using steel bracing and shear wall have smaller value than the existing structure. The retrofitting provides great rigidity to the structure, so it reduces the shear force in the structure by a round $90 \%$.Table 6 shows a comparison of bending moment on the beam. As seen in the table, the bending moment of the beam was also reduced upto $70 \%$ duetothepresent of shear wall and steel bracing in the building.
Table 5: Comparison of shear force in the beam between existing and retrofitted structures

\begin{tabular}{|c|c|c|c|c|c|c|}
\hline \multicolumn{7}{|c|}{ Shear Force (kg) } \\
\hline $\begin{array}{l}\text { Bea } \\
\text { m }\end{array}$ & $\begin{array}{l}\text { Sto } \\
\text { ry }\end{array}$ & Exist & B & $\mathrm{D}$ & F & G \\
\hline Int. & 1 & $\begin{array}{l}2068 \\
4\end{array}$ & $\begin{array}{l}1773 \\
2\end{array}$ & $\begin{array}{l}1474 \\
6\end{array}$ & $\begin{array}{l}1542 \\
3\end{array}$ & $\begin{array}{l}1561 \\
5\end{array}$ \\
\hline & 2 & 3337 & 2553 & 1906 & 1867 & 1791 \\
\hline Ext. & 1 & 6649 & 4298 & 3152 & 3560 & 4025 \\
\hline & 2 & 376 & 248 & 248 & 219 & 242 \\
\hline
\end{tabular}

Table 6: Comparison of bending moment in the beam between existing and retrofitted structures

\begin{tabular}{|c|c|c|l|l|l|l|}
\hline \multicolumn{7}{|c|}{ Bending Moment (kg) } \\
\hline $\begin{array}{c}\text { Bea } \\
\text { m }\end{array}$ & $\begin{array}{c}\text { Sto } \\
\text { ry }\end{array}$ & $\begin{array}{c}\text { Exis } \\
\mathrm{t}\end{array}$ & \multicolumn{1}{c|}{ B } & \multicolumn{1}{c|}{ D } & F & G \\
\hline Int. & 1 & $\begin{array}{l}1901 \\
8\end{array}$ & $\begin{array}{l}1722 \\
6\end{array}$ & $\begin{array}{l}1404 \\
6\end{array}$ & $\begin{array}{l}1577 \\
3\end{array}$ & $\begin{array}{l}1622 \\
3\end{array}$ \\
\hline & 2 & 5347 & 2469 & 1409 & 1199 & 1121 \\
\hline Ext. & 1 & 5092 & 3822 & 2815 & 3421 & 3797 \\
\hline & 2 & 258 & 131 & 127 & 119 & 125 \\
\hline
\end{tabular}

\subsection{The Internal Force in Columns}

The comparison of internal force in the columns (axial, shear, and bending moment) between exsisting and retrofitted buildings can be seen in Tables 7, 8, and9, respectively. It can be seen from Table 7 , the axial force on Models B and D were lower around 20 $-35 \%$ than existing building, however, on Models $\mathrm{F}$ and $\mathrm{G}$, were higher around $32-35 \%$ than existing building. From Table 8, shear force in the retrofitted 
structures were smaller than the existing structure. The percentage of reduction that occurs in the shear force of the columns are around $90-95 \%$. This is mainly due to the retrofit can resist the lateral loads, especially the earth quaked load.

Adding the shear wall and steel bracing systems on the building structure can reduce bending moment. The percentage of bending moment reduction around $95 \%$ compared to the existing structure, as seen in the Table 9.

Table 7: Comparison of axial force in the columns between the existing and the retrofitted structures

\begin{tabular}{|c|c|c|c|c|c|c|}
\hline \multicolumn{7}{|c|}{ Axial Force (kN) } \\
\hline Col. & Story & Exist & B & D & F & G \\
\hline Int & 1 & 76,6 & 29,89 & 16,53 & 121,8 & 123,63 \\
\hline & 2 & 24,86 & 10,97 & 6,22 & 9,46 & 8,61 \\
\hline Ext. & 1 & 61,16 & 4,37 & 57,16 & 64,62 & 64,87 \\
\hline & 2 & 17,55 & 0,89 & 0,56 & 12,14 & 12,15 \\
\hline
\end{tabular}

Table 8: Comparison of shear force in the columns between the existing and the retrofitted structures

\begin{tabular}{|l|l|l|l|l|l|l|}
\hline \multicolumn{7}{|c|}{ Shear Force (kN) } \\
\hline Col. & Story & Exist & \multicolumn{1}{|c|}{ B } & D & F & \multicolumn{1}{|c|}{ G } \\
\hline Int & 1 & 68,91 & 2,77 & 0,68 & 0,61 & 0,73 \\
\hline & 2 & 22,09 & 9,83 & 8,65 & 0,51 & 0,6 \\
\hline Ext. & 1 & 77,53 & 24,71 & 3,26 & 14,62 & 14,93 \\
\hline Col. & 2 & 6,83 & 6,18 & 0,74 & 3,16 & 3,52 \\
\hline
\end{tabular}

Table 9: Comparison of bending moment in the columns between the existing and the retrofitted structures

\begin{tabular}{|c|l|l|l|l|l|l|}
\hline \multicolumn{7}{|c|}{ Bending Moment (kNm) } \\
\hline Col & Story & Exist & B & D & F & G \\
\hline Int. & 1 & 134,86 & 8,44 & 4,22 & 3,27 & 4,04 \\
\hline & 2 & 38,78 & 19,28 & 17,57 & 0,87 & 1,04 \\
\hline Ext. & 1 & 145,25 & 28,1 & 1,79 & 17,61 & 17,65 \\
\hline & 2 & 40,47 & 38,8 & 22,07 & 20,26 & 20,21 \\
\hline
\end{tabular}

\subsection{Displacements}

Comparison of $\mathrm{X}$ and $\mathrm{Y}$ direction displacements in interior and exterior columns between exsisting and retrofitted structures can be seen in Figures 8 and 9. As seen in the figures, the displacement of the exterior column in $\mathrm{x}$ and $\mathrm{y}$ direction in retrofitted structure was reduced around $99 \%$ of the existing structure.
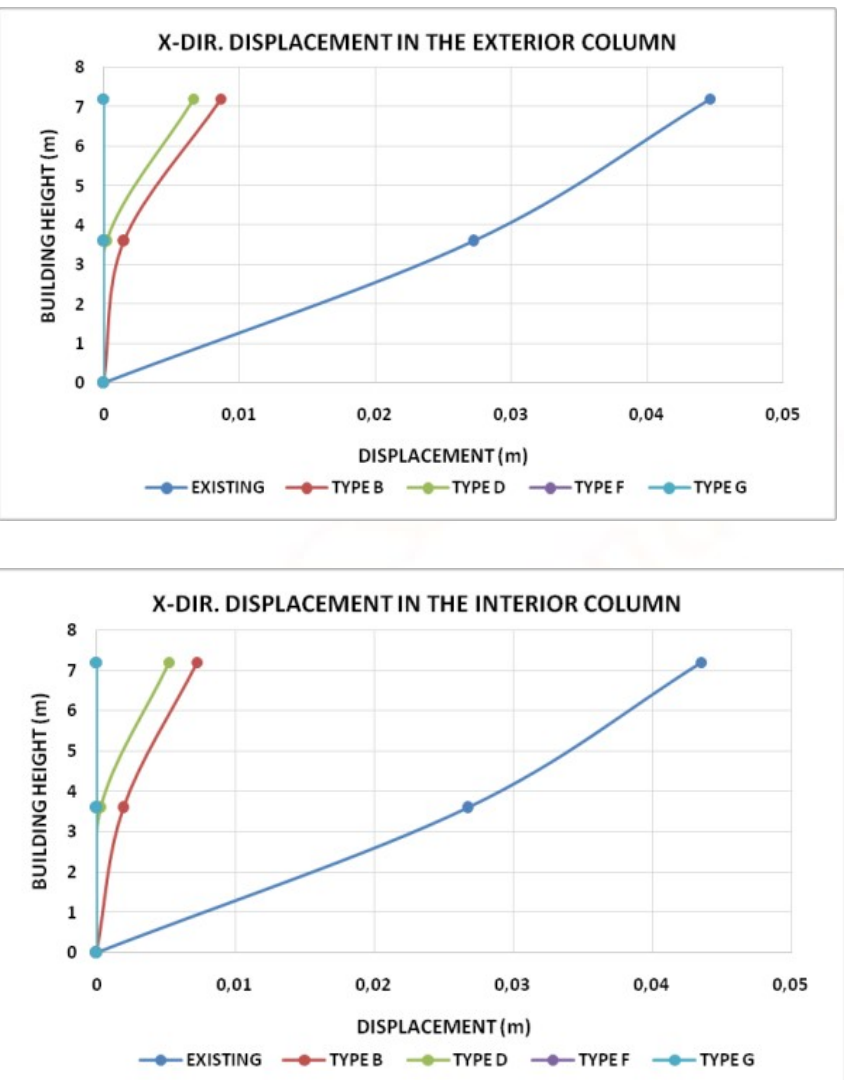

Figure8. Comparison of X-dir. displacement between existing and retrofitted structures
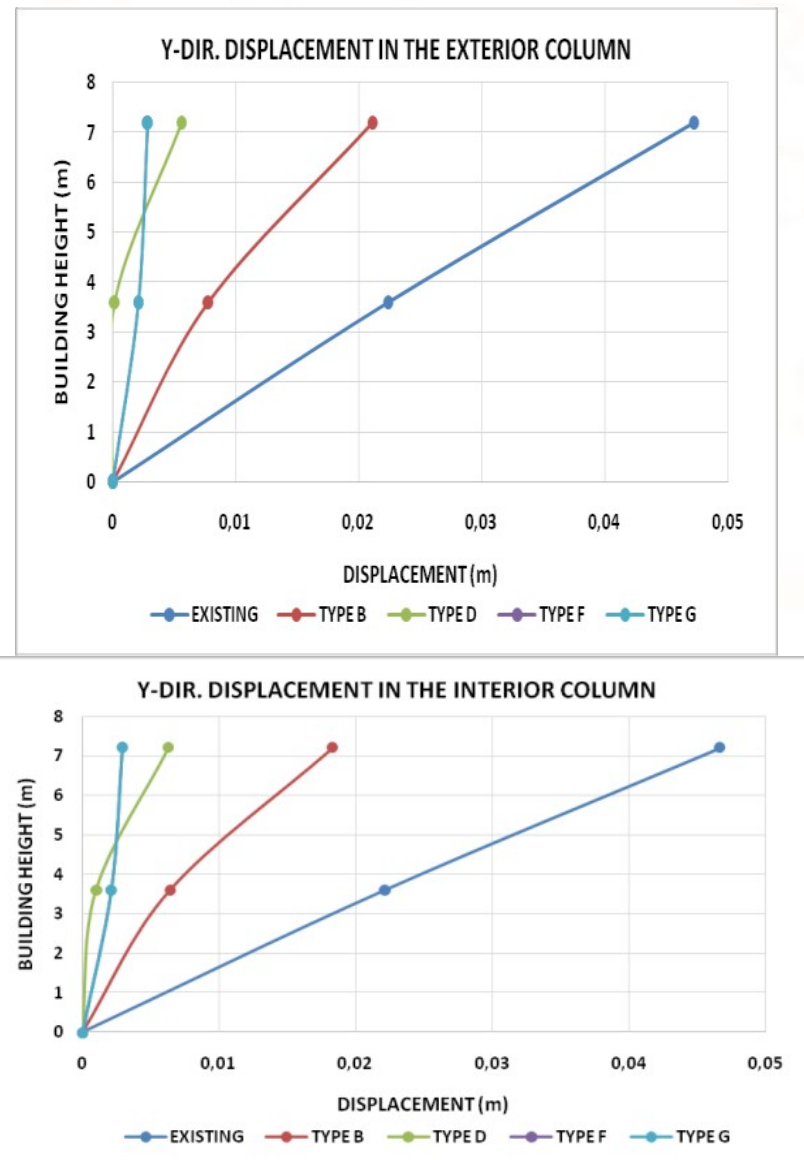

Figure9. Comparison of Y-dir. displacement between existing and retrofitted structures 
International Journal of Trend in Scientific Research and Development (IJTSRD) | ISSN: 2456-647

\subsection{Interaction diagram of the columns after retrofitting}

Figure 10 shows the P-M interaction diagram of column on the four models of retrofitted building structures. From the figure, it can be seen that the axial forces and bending moments for all models are not exceeded the interaction diagram, that means the capacity of column is strong enough to resist the working loads

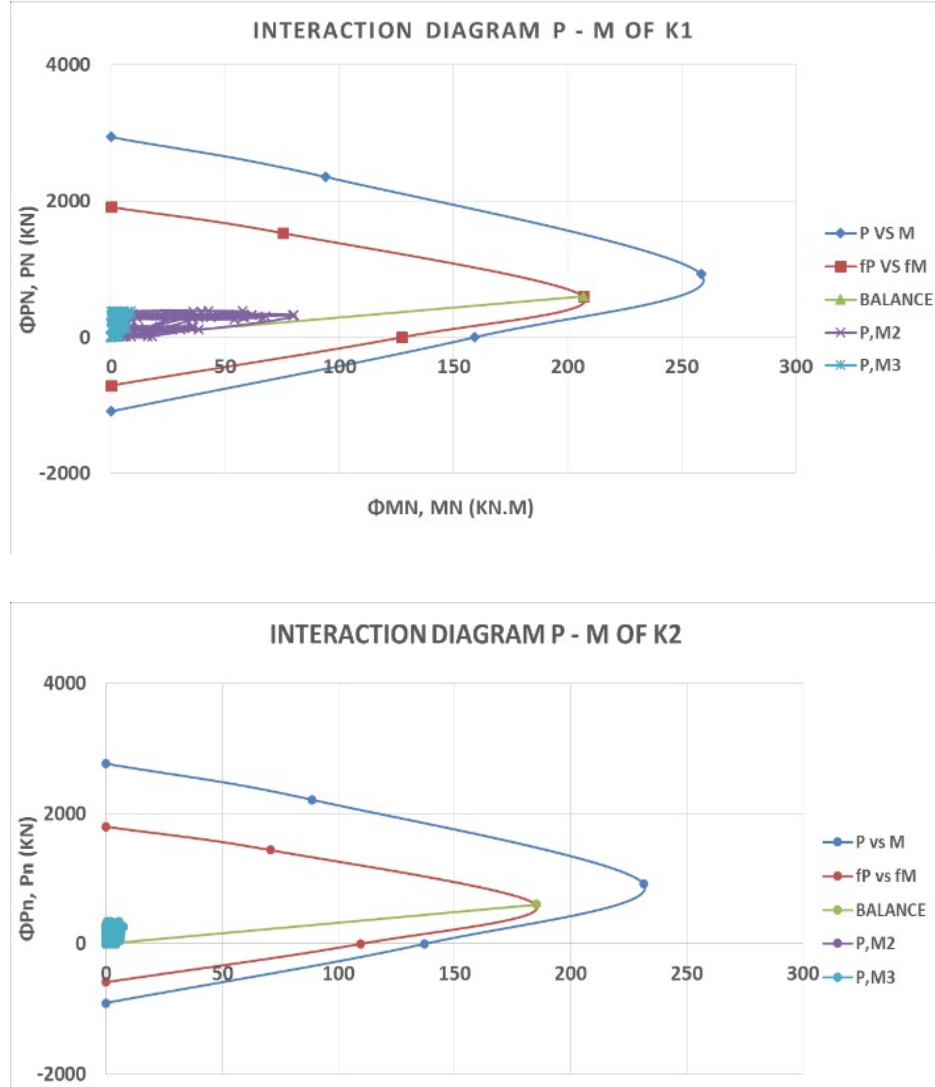

$\Phi \mathrm{Mn}, \mathrm{Mn}$ (KN.M)

(a) Model B

(b)

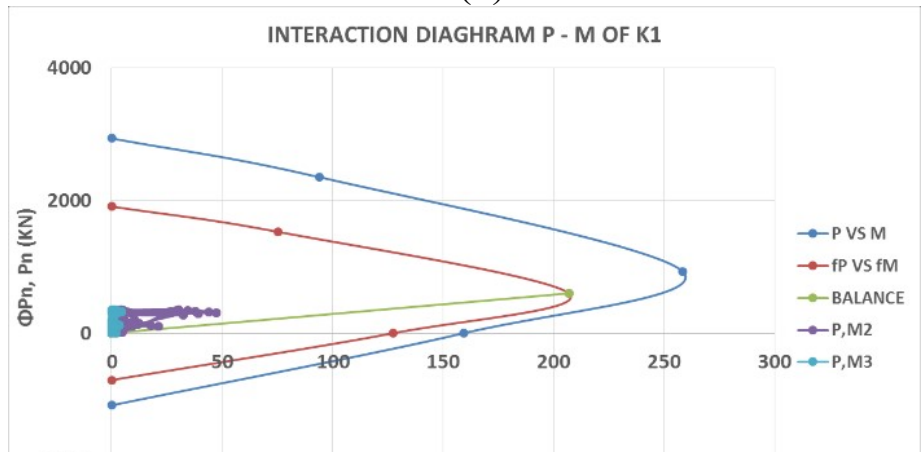

$-2000$

$\Phi \mathrm{Mn}, \mathrm{Mn}(\mathrm{KN} . \mathrm{M})$

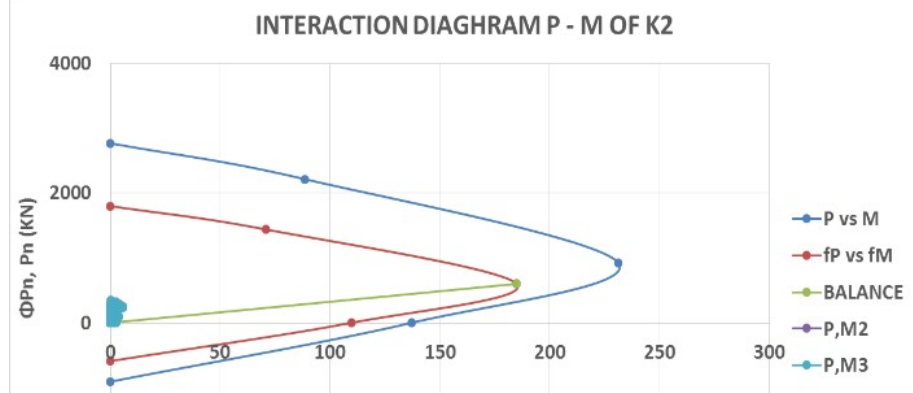

$\Phi \mathrm{Mn}, \mathrm{Mn}(\mathrm{KN} . \mathrm{M})$

(b) Model D

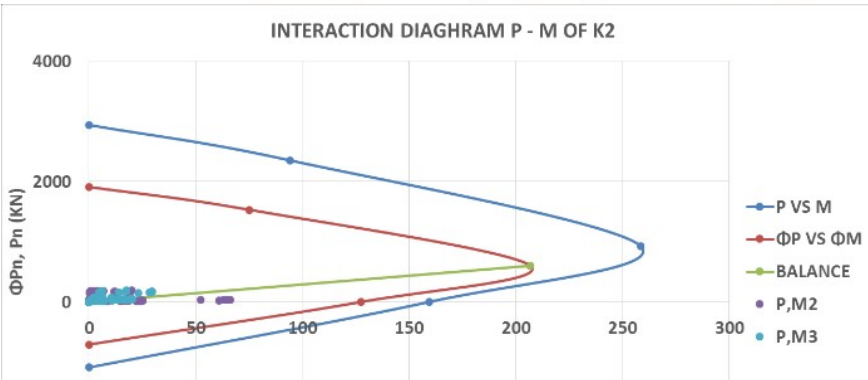

$-2000$

$\Phi M n, M n(K N . M)$

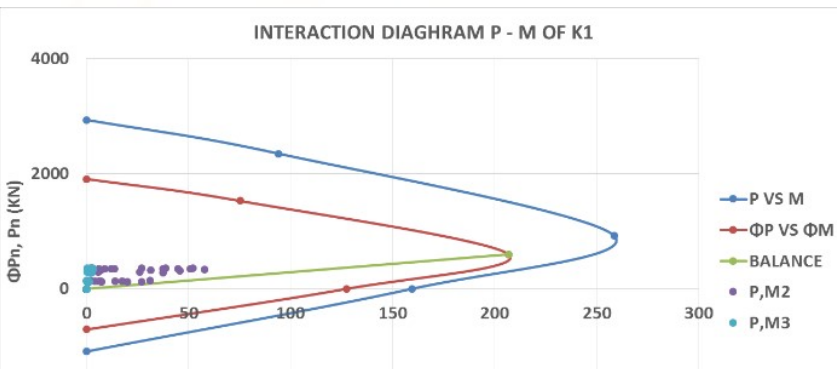

$-2000$

$\Phi M n, M n(K N . M)$

(c) Model F

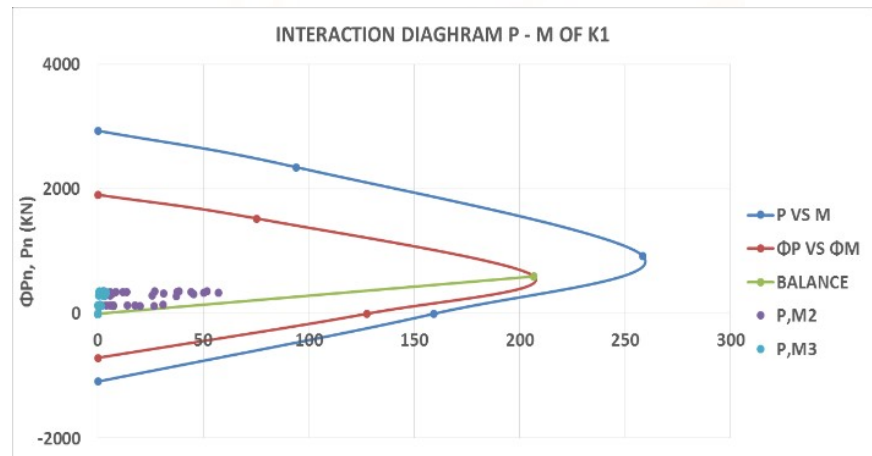

$\Phi M n, M n(K N . M)$ 


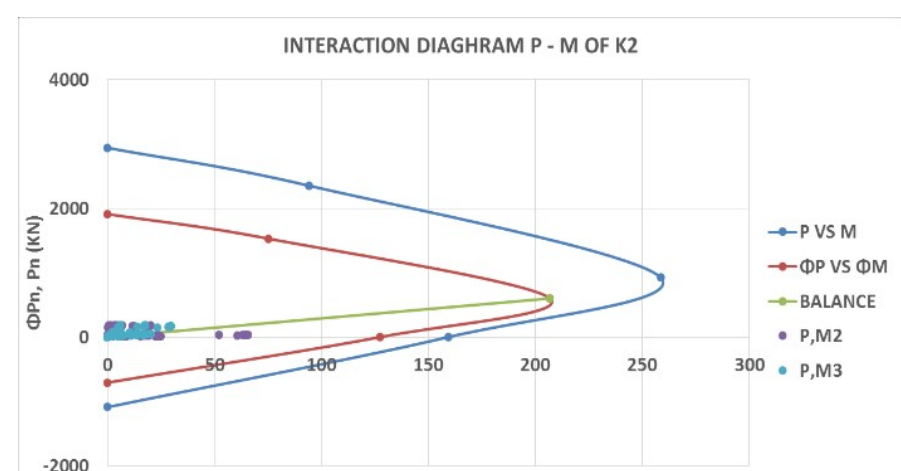

$\Phi \mathrm{Mn}, \mathrm{Mn}(\mathrm{KN} . \mathrm{M})$

(d) Model G

\subsection{Cost and volume of the work}

Table 10 shows the comparison of the cost of retrofitted building for the four retrofitted building models which analyzed by Unit Price of Work of Batusangkar City, 2017 [10]. The table shows that the use of shear wall has cost minimum Rp. 253.044.039,(Model B), whereas the use of steel bracing required lower cost, particularly of Model F, which amounted Rp. 192.125.000,-.

Table 10: Comparison of the retrofit structure cost

\begin{tabular}{|l|l|l|c|}
\hline \multicolumn{1}{|c|}{$\begin{array}{c}\text { Retrofit } \\
\text { Method (1) }\end{array}$} & \multicolumn{1}{|c|}{$\begin{array}{c}\text { Volume } \\
\text { (2) }\end{array}$} & $\begin{array}{c}\text { Unit Price } \\
\text { per Volume } \\
(3)\end{array}$ & $\begin{array}{c}\text { Cost of } \\
\text { Material } \\
(4)=2 \times \text {. 3 }\end{array}$ \\
\hline $\begin{array}{l}\text { Model } \\
\text { B(SW) }\end{array}$ & $39,6 \mathrm{m3}$ & $\begin{array}{l}\text { Rp. } \\
6.390 .000\end{array}$ & 253.044 .039 \\
\hline $\begin{array}{l}\text { Model } \\
\text { D(SW) }\end{array}$ & $50,4 \mathrm{m3}$ & $\begin{array}{l}\text { Rp. } \\
6.390 .000\end{array}$ & 322.056 .050 \\
\hline $\begin{array}{l}\text { Model } \\
\text { F(SB) }\end{array}$ & 15370 & Rp. 12.500 & 192.125 .000 \\
\hline $\begin{array}{l}\text { Model } \\
\text { G(SB) }\end{array}$ & 17291 & $\mathrm{Rp} .12 .500$ & 216.140 .000 \\
\hline
\end{tabular}

\section{CONCLUSION}

From the above structural analysis, it can be concluded that:

1. The building of SMA N 3 Batusangkar is unable to resist the working loads based on the evaluation of the feasibility structure which analyzed using SNI 1726-2012. The structure should be retro fitted.

2. Retrofitted of the building by adding steel bracing and shear wall systems are very effective for reducing the displacement by 60 $99 \%$ and the internal force by $10-95 \%$ compared to the existing structure.

3. Models B and D which used shear wall system, and models $\mathrm{F}$ and $\mathrm{G}$ used steel bracing system can be applied in the retrofitted school building to reduce the internal force and displacement due to the working loads.

4. Retrofitted using steel bracing system is more economical and easier to be installed than the shear wall, so the method of retrofit using steel bracing models $\mathrm{F}$ and $\mathrm{G}$ are very recommended for strengthening the structure of SMA N 3 Batusangkar, which it can also be applied to other typical school buildings.

\section{REFERENCES}

1. Disaster of Management Coordination Board of West Sumatra, (2009), The Map of Total Damage Public Facilities caused Earthquake in West Sumatra, Indonesia.

2. National Standardization Agency of Indonesia, (2002), Design Standard of Earthquake Resistance for Buildings, SNI 03-1726-2002, Jakarta, Indonesia.

3. National Standardization Agency of Indonesia, (2012), Design Method of Earthquake Resistance for Buildings and Other Structures, SNI 17262012, Jakarta, Indonesia.

4. Computers and Structures, Inc., (2005), Manual ETABS (Integrated Building Design Software). California, USA.

5. National Standardization Agency of Indonesia, (2003), Minimum load for the design of buildings and other structures, Jakarta, Indonesia.

6. http://puskim.pu.go.id/Aplikasi/desain_spektra_ indonesia_2011/

7. Central Public Works Department and Indian Building Congress, (2007), Handbook on Seismic Retrofit of Buildings. Association Indian Institute Technology.

8. S., Anshuman, et al., (2011), Solution of Shear Wall Location in Multi-Story Building. IJSCE vol. 2 no. Civil Engineering Group, BITS Pilani, India.

9. M., Adhitya, et al., (2015), Study on Effective Bracing Systems for High Rise Steel Structures. SSRG-IJCE vol. 2 issue 2. Civil Engineering East West Institute of Technology, Bangalore-91, India.

10. Central Public Works Department of Batusangkar City, (2017), Work Unit Price Triwulan I 2017, Indonesia. 